\title{
Priming of $\mathbf{T}$ follicular helper (Tfh) cells by dendritic cells
}

\author{
André Ballesteros-Tato ${ }^{1}$ and Troy D. Randall, ${ }^{1,}$ \\ ${ }^{1}$ Department of Medicine, Division of Clinical Immunology and Rheumatology, University of \\ Alabama at Birmingham, Birmingham, AL 35294.
}

\section{SUMMARY}

$\mathrm{T}$ follicular helper cells ( $\mathrm{Tfh}$ ) are required to generate long-lived antibody responses, which confer long-term protection to pathogens following vaccination or infection. Despite significant advances in the field, however, little is known about the early steps that drive Tfh cell differentiation. In this review we will discuss the mechanisms by which dendritic cells (DCs)promote the initial commitment of activated $\mathrm{CD} 4^{+} \mathrm{T}$ cells to the $\mathrm{Tfh}$ cell differentiation pathway.

\section{Introduction}

The recent characterization of $\mathrm{T}$ follicular helper cells (Tfh) as a distinct subset of $\mathrm{CD} 4^{+} \mathrm{T}$ cells has significantly advanced our understanding of T cell-dependent B cell responses. Tfh cells are a unique subset of $\mathrm{CD} 4^{+} \mathrm{T}$ cells that express high levels of the transcription factor, Bcl6, and promote the differentiation of activated, antigen-specific B cells into memory B cells as well as long-lived plasma cells ${ }^{1-3}$. The chemokine receptor, CXCR5, is a characteristic marker of Tfh cells and promotes their homing to the B cell follicles and germinal centers, where they provide differentiation and survival signals ( $T$ cell help) to B cells - hence the name $\mathrm{T}$ follicular helper cells. Numerous studies over the last few years contribute to our understanding of the essential role played by this specialized subset of $\mathrm{CD}^{+} \mathrm{T}$ cells in the generation and maintenance of long-term humoral immunity ${ }^{1}$. In fact, without Tfh cells, germinal centers do not develop, long-lived plasma cells are not generated and long-term antibody responses are impaired ${ }^{4-7}$. However, the molecular mechanisms and the cellular interactions that regulate Tfh cell fate commitment are still unclear.

Recent advances in Tfh cell biology reveal that antigen presentation by dendritic cells (DCs) is necessary and sufficient to initiate Tfh cell commitment ${ }^{8-11}$, despite the fact that in most cases, antigen presentation by B cells is ultimately responsible for promoting the full differentiation program of Tfh cells. Thus, by determining the cellular and molecular mechanisms used by DCs to initiate Tfh cell commitment, we may be able to target antigens specifically to those DCs that induce Tfh cells or develop adjuvants that preferentially activate DCs to promote Th cell priming. In this review, we will discuss recent findings regarding how DCs promote Tfh cell differentiation and whether $\mathrm{T}$ effector and Tfh cell responses may be differentially controlled by DCs.

*Correspondence: Troy Randall, PhD Department of Medicine Division of Clinical Immunology and Rheumatology University of Alabama at Birmingham Birmingham, AL, 35294 randallt@uab.edu Phone: 205-975-3323 Fax: 205-975-3322. 


\section{Evidence for a role of DCs in priming Tfh cell responses}

The commitment of naïve $\mathrm{CD} 4^{+} \mathrm{T}$ cells into the Tfh cell differentiation pathway depends on the expression of the transcription factor, $\mathrm{Bcl} 6$, which represses the expression of other $\mathrm{T}$ cell subset-specific transcription factors and promotes the sustained expression of CXCR5 ${ }^{5-7}$. Early studies show that priming of Bcl6-expressing Tfh cells requires the interaction of naïve $\mathrm{CD} 4^{+} \mathrm{T}$ cell with antigen-presenting $\mathrm{B}$ cells $5,6,12,13$. These observations suggest a binary model in which primed $\mathrm{CD} 4^{+} \mathrm{T}$ cells either encounter activated B cells at the border of the B cell follicle, where they are instructed to differentiate into Tfh cells, or they encounter DCs within the T cell area and differentiate into effector $\mathrm{CD}^{+} \mathrm{T}$ cells ${ }^{1}$. However, recent data challenge this view and indicate that, although antigen presentation by activated B cells is important for the maintenance of Tfh cell responses, antigen presentation by DCs is necessary and sufficient to induce the initial expression of Bcl6, CXCR5 and ICOS and to launch the Tfh cell differentiation program ${ }^{8-11,14 .}$

In fact, the up-regulation of Bcl6 and commitment to the Tfh differentiation pathway occurs rapidly after immunization or infection $8,11,14,15$ and takes place outside the $\mathrm{B}$ cell follicle in the absence of B cells ${ }^{14,15}$. For example, Bcl6 and CXCR5 expression on CD4 ${ }^{+} \mathrm{T}$ cells occurs as early as the second cell division following viral infection and does not required the presence of $\mathrm{B}$ cells ${ }^{8}$. Moreover, SAP-deficient $\mathrm{CD} 4{ }^{+} \mathrm{T}$ cells, which fail to establish sustained interactions with cognate $\mathrm{B}$ cells, but interact normally with antigen-presenting $\mathrm{DCs}^{16}$, up-regulate Bcl6 and CXCR5 following activation ${ }^{8,10}$ and migrate into the B cell follicles ${ }^{10}$ - both traits of Tfh cells. Together, these results suggest that some aspects of Tfh differentiation are initiated prior to contact with B cells, most likely following interaction with DCs. However, the most compelling evidence in favor of a role for DCs in Tfh cell priming comes from a recent study using mice in which MHC class II expression is restricted to conventional DCs and is absent from B cells ${ }^{9}$. In this study, the authors elegantly demonstrate that cognate-interactions with antigen-presenting DCs are necessary and sufficient to trigger the initial steps of Tfh differentiation, including turning on the expression of Bcl6, CXCR5 and ICOS and promoting the physical homing of responding $\mathrm{CD} 4^{+} \mathrm{T}$ cells to the $\mathrm{B}$ cell follicle.

Importantly, even though the ability of $\mathrm{CD}^{+}{ }^{+} \mathrm{T}$ cells to up-regulate $\mathrm{Bcl} 6$ and $\mathrm{CXCR} 5$ and to home to B cell follicles does not necessarily require cognate-interactions with B cells, the full differentiation of $\mathrm{Tfh}$ cells and their long-term maintenance are typically impaired in the absence of B cells 5, 9, 12, 15, 17, or when B cells do not express MHC class II molecules 9,10 . Based on these results, some authors suggest that naïve CD4 T cells first contact DCs outside the $\mathrm{B}$ cell follicle ${ }^{15,18}$, where they are primed, begin to proliferate and some of them acquire low levels of CXCR5 and Bcl6 ${ }^{8,9}$. These early pre-Tfh cells subsequently migrate to the border between the $\mathrm{B}$ cell follicle and $\mathrm{T}$ cell zone, where they encounter antigen-activated $\mathrm{B}$ cells ${ }^{8}$ and receive additional and unique survival and differentiation signals that are required to complete the Th cell differentiation program and to sustain prolonged Tfh cell responses $5,12,13,19$. Supporting this model, the expansion of the Tfh cell response is impaired when B cells do not express certain costimulatory molecules, such as ICOS ligand ${ }^{8}$ or PD-1 ligand ${ }^{20}$. 
Although cognate interactions with activated B cells are typically required to sustain DCprimed Tfh cells, late B cell-mediated antigen presentation is not required when antigen is in excess 9,10 . In fact, DCs can substitute for B cells as antigen-presenting cells and support prolonged Tfh cell responses when mice receive an antigen boost ${ }^{9,10}$. These studies indicate that $\mathrm{B}$ cells are not required to provide a unique signal that promotes (or sustains) Tfh cell differentiation later on in the immune response. Instead, antigen-specific B cells only become the principal antigen-presenting cells when antigen availability is limited 9,10 . This model is consistent with recent findings showing that maintenance of the Tfh cell phenotype requires sustained antigenic stimulation 19,21 and with previous data demonstrating that, compared to DCs, B cells are particularly efficient antigen-presenting cells when antigen is limited due to their capacity to capture antigen through their high affinity antigen-B cell receptor ${ }^{22}$. Collectively, these data suggest that antigen availability dictates the transition from DC-dominated Tfh cell priming to B cell-dominated Tfh cell expansion and maintenance.

\section{The role of DCs in the spatial compartmentalization of effector and Tfh cell differentiation}

Naïve CCR7-expressing CD4 ${ }^{+} \mathrm{T}$ cells are thought to encounter recently-activated, CCR7expressing, antigen-bearing DCs within the T cell area of secondary lymphoid organs ${ }^{23}$, where they subsequently differentiate into effector $\mathrm{T}$ cells following exposure to polarizing cytokines secreted by the DCs ${ }^{24,25}$. In this model, the cytokines made the DCs are the main driving force behind the subsequent differentiation of $\mathrm{T}$ cells towards a polarized effector phenotype. However, several lines of evidence indicate that, in addition to the polarizing cytokines secreted by DCs, the spatial location of the responding T cells within the secondary lymphoid organ is also an important factor in their subsequent differentiation ${ }^{26-29}$. For example, a recent study ${ }^{15}$ indicates that $\mathrm{Tfh}$ cells are initially primed within the interfollicular zone - the narrow strip between B cell follicles that, despite being on the edge of the $\mathrm{B}$ cell area, is also not in the $\mathrm{T}$ cell zone.

The idea that the interfollicular zone is important for Tfh differentiation represents a paradigm shift from the original idea that pre-Tfh cells up-regulate CXCR5, down-regulate CCR7 and migrate to the T-B border, where they interact with B cells ${ }^{12,3031}$. Instead, the new studies suggest that pre-Tfh cells turn on CXCR5, migrate to the interfollicular zone and up-regulate Bcl6 expression independently of any cognate interactions with B cells 15,32 - implying that other antigen-presenting cells, such as DCs, are promoting the expression of both CXCR5 and Bcl6 ${ }^{9,10,15,33}$. Although DCs predominate in the T zone, conventional DCs are also found in the B cell follicle and in the interfollicular areas $28,34,35$, where they may transfer antigen to B cells and help primary antibody responses ${ }^{36}$. Importantly, DCs found near the B cell follicles also express high levels CXCR5, low levels of CCR7 and migrate in response to CXCL13 28, 35, 36. Thus, the expression of CXCR5 by DCs is likely to be instrumental in their placement near the $\mathrm{B}$ follicles and their ability to promote Tfh cell responses.

Despite the potential role of CXCR5-expressing DCs in the priming of Tfh responses, it is not clear whether Tfh cell priming is conducted by a specific subset of CXCR5-expressing 
DCs that are specialized in priming Tfh cells or whether any DC that receives the appropriate activating signals will up-regulate CXCR5, but not CCR7, migrate to the interfollicular zone and promote the differentiation of Tfh cells. In favor of the DC subset hypothesis, myeloid DCs in secondary lymphoid organs can be broadly separated into two major categories, resident DCs (rDCs) and migratory DCs (mDCs), based on their anatomic origin ${ }^{37-42}$. Whereas rDCs reside constitutively in secondary lymphoid organs and capture and present antigen that access the lymphoid organs directly through the blood or lymph, $\mathrm{mDCs}$ differentiate in the peripheral tissues and, upon activation, migrate into draining lymph nodes via afferent lymphatic vessels (Table I). Importantly, mDCs characteristically express high levels of CCR7, whereas rDCs display low levels of this chemokine receptor ${ }^{43}$, suggesting that if $\mathrm{rDCs}$ were to also up-regulate CCR5, they could migrate to the interfollicular zone and prime Tfh cells. In contrast, the high levels of CCR7 found on most $\mathrm{mDCs}$ would promote their homing to the $\mathrm{T}$ zone and preclude their priming of $\mathrm{Tfh}$ cells $2328,44-47$.

Interestingly, numerous studies indicate that $\mathrm{mDCs}$ can carry antigens from peripheral tissues into draining lymph nodes and subsequently transfer those antigens to rDCs ${ }^{48-51}$. Therefore, one could envision a scenario in which $\mathrm{CCR} 7^{+} \mathrm{mDCs}$ may hand off antigen to $\mathrm{CCR}^{-}$rDCs, which then turn on CXCR5, migrate into the interfollicular area and promote Tfh differentiation. Alternatively, although activation through pathogen recognition receptors often triggers CCR7 expression on migratory DCs, mDCs can also up-regulate CXCR5 (without up-regulating CCR7) in response to some pathogens, and as a consequence, preferentially home into the interfollicular area after reaching the draining lymph node ${ }^{28}$. These data suggest that, at least in some circumstances, mDCs might upregulate CXCR5 and home into the interfollicular zone to directly prime Tfh cells responses. In a third scenario, some mDC populations may migrate from the infected tissues to the draining lymph node by a CXCR3-dependent mechanism ${ }^{52}$ and, following a stromal cellderived CXCL9 gradient ${ }^{27}$, access the interfollicular area and promote Tfh cell responses ${ }^{52}$. In each of these scenarios, a specific subset of DCs or activation state of DCs is required to prime Tfh responses in the interfollicular zone, suggesting that a specific subset of Tfh-activating DCs should be able to be identified and targeted during vaccination.

An important remaining question is why encounters between activated T cells and DCs within the interfollicular zone facilitate Bcl6 up-regulation and Tfh cell differentiation. Interestingly, in addition to regulating lymphocyte trafficking, chemokine-chemokine receptor interactions also modulate the activation and maturation of monocytes and DCs ${ }^{53}$. Indeed, DCs up-regulate costimulatory molecules and secrete pro-inflammatory cytokines in response to CCL19 and CCL21 and preferentially prime Th1 responses after CCR7 stimulation ${ }^{54,55}$. On the basis of these findings, one could speculate that, in addition to orchestrating encounters between DCs and T cells, chemokine-chemokine receptor interactions also condition the capacity of DCs to prime Tfh cell responses by regulating the expression of co-stimulatory molecules and inflammatory cytokines required for Tfh cell development (Figure 1). For example, whereas the engagement of CCR7 on DCs could program them to preferentially prime polarized Th1 responses, the engagement of CXCR5 on DCs may preferentially condition them to initiate Tfh cell responses. Alternatively, the 
positioning of DCs within the particular microenvironment of the interfollicular area may allow them to receive conditioning signals from nearby B cells or stromal cells that ultimately instruct them to induce Tfh cell differentiation. Consistent with this last possibility, the differentiation of IL-4-producing Tfh cells requires interactions with lymphotoxin-conditioned stromal cells in the interfollicular zone ${ }^{28}$. Thus, environmental triggers may be as important as cytokines in promoting Tfh differentiation.

\section{Influence of DC-derived cytokines in Tfh cell development}

The differentiation of activated $\mathrm{CD} 4^{+} \mathrm{T}$ cells into $\mathrm{Tfh}$ or polarized effector $\mathrm{T}$ cells is finetuned by the balance of cytokines that promote $\mathrm{Tfh}$ differentiation and those that prevent $\mathrm{Tfh}$ cell differentiation ${ }^{56,57}$. For example, whereas IL-6 ${ }^{58-60}$ and IL-21 6061 cooperate to induce Tfh cell formation by activating STAT3, which in turn promotes Bcl6 and CXCR5 expression, IL-2 signaling prevents Tfh cell development via STAT5 activation ${ }^{4,62,63}$. The differential activation of DCs by pathogens or adjuvants enhances their production of a wide range of cytokines that work cooperatively to guide the responding $\mathrm{T}$ cells down the various pathways of differentiation 24,25 . In a similar way, DCs may play important roles in controlling induction of Tfh cell responses by regulating the balance between the cytokines required for $\mathrm{Tfh}$ differentiation and those required for effector $\mathrm{T}$ cell polarization.

\section{DC-derived IL-6}

Despite abundant evidence suggesting an important role for IL-6 in Tfh cell development ${ }^{58-60,64}$, the relevant cellular source of IL-6 in vivo remains unclear. Recent studies suggest that early IL-6 signaling is required to initiate the Tfh differentiation program following acute viral infection ${ }^{58}$. Activated conventional DCs secrete large amounts of IL-6, particularly in response to CD40 stimulation ${ }^{65}$, 66 . Interestingly, type I interferon is required to license CD40-dependent IL-6 secretion by DCs and, as a result,

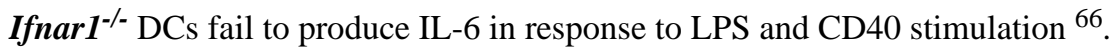

AlthoughIfnar1 ${ }^{--} \mathbf{C D 8}^{+} \mathbf{T}$ cells fail to differentiate into fully functional cytolytic effector cells following viral infections in vivo, Ifnar $\mathbf{1}^{-/-} \mathrm{CD} 4^{+} \mathrm{T}$ cells differentiate normally into Tfh cells. However, Tfh cell responses are impaired in mice in which Infar1 deficiency is restricted to DCs. Based on these results, one could argue that DCs stimulated by CD40 in the presence of type I Interferon would preferentially trigger Tfh cell differentiation by promoting Bc16 up-regulation via STAT3 and STAT1 activation following IL-6 signaling ${ }^{58}$.

Plasmacytoid DCs (pDCs) also secrete IL-6 upon activation by microbial products 6768,69 and may play a role in promoting Tfh cell differentiation. For example, ICOS expression, which is required for Tfh cell differentiation ${ }^{8}$, is induced on $\mathrm{T}$ cells in response to $\mathrm{pDC}$ derived IL- ${ }^{70}$. Moreover, pDCs also up-regulate ICOS-ligand in response to influenza $7170,72,73$, suggesting that $\mathrm{pDCs}$ could contribute to the Tfh cell pathway by promoting interactions between ICOS and its ligand ${ }^{70}$. Consistent with this idea, a recent study shows that the antibody response to influenza is impaired in pDC-depleted mice ${ }^{74}$. Thus, the production of IL- 6 by both conventional DCs and pDCs may promote Tfh differentiation. 
IL-6 production by DCs is triggered by exposure to microbial products and by interactions with T cells via CD40. However, the production of IL- 6 by DCs can also be repressed under some circumstances. For example, recent studies suggest that BLIMP-1-1 negatively regulates the capacity of activated DCs to secrete IL- $6{ }^{75,7618}$. In fact, BLIMP-1 deficient DCs preferentially induce Tfh cell differentiation in vitro ${ }^{19}$ and mice lacking BLIMP-1 in the DC compartment produce high levels of IL- 6 and exhibit spontaneous germinal center formation and autoantibody production. Thus, in addition to directly inhibiting Tfh cell differentiation by preventing Bcl6 expression in T cells ${ }^{5}$, Blimp-1 may also prevent Tfh cell responses by regulating the capacity of conventional and pDCs to produce IL- 6 and thereby instruct Tfh cell priming.

\section{DC-derived IL-2}

IL-2 is often thought of as the canonical growth factor for both $\mathrm{CD} 4^{+}$and $\mathrm{CD} 8^{+} \mathrm{T}$ cells. However, despite its potent effects on $\mathrm{T}$ cell proliferation and the differentiation of effector T cells, IL-2 signaling through the IL-2R expressed on T cells actually prevents Tfh cell differentiation ${ }^{4}$. IL-2 likely disrupts the differentiation of Tfh by promoting BLIMP-1 expression via STAT5 ${ }^{62,63}$, or by inducing the expression of T-bet, which forms complexes with Bcl6 that mask the DNA-binding domain of Bcl6 and prevent Bcl6 from repressing the expression of BLIMP-1 77 . Although activated $\mathrm{CD} 4^{+} \mathrm{T}$ cells are often considered the principal source of IL-2 during the course of an immune response, DCs also produce significant amounts of IL-2 in response to various microbial stimuli ${ }^{78,79}$. Indeed, DCs engaged in cognate interactions with $\mathrm{T}$ cells secrete IL-2 in a directed fashion towards the $\mathrm{T}$ cell-DC interface ${ }^{79}$, a process that may help expand both $\mathrm{CD} 4{ }^{+}$and CD8+ T cell effectors. Moreover, some viruses infect DCs and actively prevent them from secreting IL-2 ${ }^{80}$, thus limiting the capacity of DCs to expand responding T cells and highlighting the importance DC-derived IL-2 in promoting T cell responses against viruses. Therefore, given that IL-2 signaling is required for effector $\mathrm{T}$ cell differentiation ${ }^{81,82}$, but precludes Tfh cell formation $^{13-15,21}$, contact of naïve CD4 T cells with IL-2-producing DCs may favor effector $\mathrm{T}$ cell development at expense of Tfh cell formation 4, 62, 63,77.

Although IL-2 clearly acts directly on T cells via CD25 to impair the differentiation of Tfh cells, IL-2 may act on more than just T cells to prevent Tfh differentiation. For example, CD25 expression is not restricted to T cells, and is also found on human 83,84 and mouse DCs ${ }^{85}$. Given that IL-2 signaling drives BLIMP-1 expression in T cells, it may also promote BLIMP-1 expression in DCs. In turn, BLIMP-1-expressing DCs should produce less IL-6, leading to a bias in CD4+ T cell differentiation away from the production of Tfh cells. Consistent with this idea, BLIMP-1-deficient DCs promote the expansion of germinal centers and the production of autoantibodies in mice ${ }^{75,76}$. Thus, is possible that IL-2 signaling induces Blimp-1 expression in DCs just like it does in T cells and thereby inhibits their capacity to promote Tfh cell responses by limiting IL-6 production.

\section{DC-derived IL-12}

Activation of DCs by certain pathogen-recognition receptors, such as TLR4 or TLR7, results in the robust secretion of IL-12, which conditions responding T cells to secrete Th1 cytokines ${ }^{24,25}$. However, IL-12 has been also implicated in Tfh cell development via 
STAT4 activation, which seems to be required for early up-regulation of Bc16 and IL-21 genes, in both human and mice ${ }^{86,87}$. In fact, the induction of IL-21-secreting Tfh like-cells by human DCs is dependent on IL- $12^{88}$, suggesting that early contacts of naïve $\mathrm{CD} 4^{+} \mathrm{T}$ cells with IL-12-secreting DCs may be required to initiate the Tfh cell program. Intriguingly, using the same STAT4 dependent mechanism ${ }^{89}, 90$, IL-12 signaling also induces the upregulation of T-bet ${ }^{11,12}$, which prevents Bcl6 activity and Tfh cell development ${ }^{77,86}$. Thus, whereas IL-12 may induce early expression of Tfh cell markers, prolonged IL-12 receptor signaling may prevent $\mathrm{Tfh}$ cell responses by inducing T-bet expression. Based on this model, it is not just the presence or absence of a particular cytokine-signaling pathway that alters Tfh cell differentiation, but that the duration and intensity of some signaling pathways may control the cell fate commitment of Tfh cells. Importantly, which DC subsets produce IL-12, as well as the amount of IL-12 secreted by a particular population, depends on the kind of the microbial challenge encountered ${ }^{39,91-93}$. Thus, the nature of the activation signal could determine, at least to some degree, the capacity of the different DCs subsets to prime Tfh cells responses by conditioning their ability to secrete IL-12 upon activation.

\section{Concluding remarks}

Given that Tfh cells are required for the generation of germinal centers and the establishment of long-lived antibody responses, it is essential that we understand how to manipulate Tfh responses in order to improve the efficacy of vaccines and intervene in the case of antibody-dependent autoimmunity. Importantly, by characterizing the cellular and molecular mechanisms by which DCs control Tfh priming, we will be able to define adjuvants that boost $\mathrm{Tfh}$ cell responses and promote long-term antibody responses to vaccination. On the other hand, knowing the mechanisms by which DCs promote unregulated Tfh cell responses will lead to the design of new therapeutic approaches to inhibit the development of self-reactive Tfh cell responses, which would ultimately help to prevent effector auto-reactive B cell responses and immunopathology.

\section{Acknowledgments}

This work supported by NIH grants HL 069409, AI 061511, AI 097357 and AI100127 to TDR and by a sub-award of AR 048311 to ABT.

\section{BIBLIOGRAPHY}

1. Crotty S. Follicular helper CD4 T cells (TFH). Annual review of immunology. 2011; 29:621-63.

2. Yu D, Vinuesa CG. The elusive identity of T follicular helper cells. Trends in immunology. 2010; 31(10):377-83. [PubMed: 20810318]

3. Goodnow CC, Vinuesa CG, Randall KL, Mackay F, Brink R. Control systems and decision making for antibody production. Nature immunology. 2010; 11(8):681-8. [PubMed: 20644574]

4. Ballesteros-Tato A, Leon B, Graf BA, Moquin A, Adams PS, Lund FE, et al. Interleukin-2 inhibits germinal center formation by limiting $\mathrm{T}$ follicular helper cell differentiation. Immunity. 2012; 36(5): 847-56. [PubMed: 22464171]

5. Johnston RJ, Poholek AC, DiToro D, Yusuf I, Eto D, Barnett B, et al. Bcl6 and Blimp-1 are reciprocal and antagonistic regulators of $\mathrm{T}$ follicular helper cell differentiation. Science. 2009; 325(5943):1006-10. [PubMed: 19608860] 
6. Nurieva RI, Chung Y, Martinez GJ, Yang XO, Tanaka S, Matskevitch TD, et al. Bcl6 mediates the development of T follicular helper cells. Science. 2009; 325(5943):1001-5. [PubMed: 19628815]

7. Yu D, Rao S, Tsai LM, Lee SK, He Y, Sutcliffe EL, et al. The transcriptional repressor Bcl-6 directs T follicular helper cell lineage commitment. Immunity. 2009; 31(3):457-68. [PubMed: 19631565]

8. Choi YS, Kageyama R, Eto D, Escobar TC, Johnston RJ, Monticelli L, et al. ICOS receptor instructs $\mathrm{T}$ follicular helper cell versus effector cell differentiation via induction of the transcriptional repressor Bcl6. Immunity. 2011; 34(6):932-46. [PubMed: 21636296]

9. Goenka R, Barnett LG, Silver JS, O'Neill PJ, Hunter CA, Cancro MP, et al. Cutting edge: dendritic cell-restricted antigen presentation initiates the follicular helper T cell program but cannot complete ultimate effector differentiation. J Immunol. 2011; 187(3):1091-5. [PubMed: 21715693]

10. Deenick EK, Chan A, Ma CS, Gatto D, Schwartzberg PL, Brink R, et al. Follicular helper T cell differentiation requires continuous antigen presentation that is independent of unique $\mathrm{B}$ cell signaling. Immunity. 2010; 33(2):241-53. [PubMed: 20691615]

11. Poholek AC, Hansen K, Hernandez SG, Eto D, Chandele A, Weinstein JS, et al. In vivo regulation of Bcl6 and T follicular helper cell development. J Immunol. 2010; 185(1):313-26. [PubMed: 20519643]

12. Haynes NM, Allen CD, Lesley R, Ansel KM, Killeen N, Cyster JG. Role of CXCR5 and CCR7 in follicular Th cell positioning and appearance of a programmed cell death gene-1high germinal center-associated subpopulation. J Immunol. 2007; 179(8):5099-108. [PubMed: 17911595]

13. Glatman Zaretsky A, Taylor JJ, King IL, Marshall FA, Mohrs M, Pearce EJ. T follicular helper cells differentiate from Th2 cells in response to helminth antigens. The Journal of experimental medicine. 2009; 206(5):991-9. [PubMed: 19380637]

14. Baumjohann D, Okada T, Ansel KM. Cutting Edge: Distinct waves of BCL6 expression during T follicular helper cell development. J Immunol. 2011; 187(5):2089-92. [PubMed: 21804014]

15. Kerfoot SM, Yaari G, Patel JR, Johnson KL, Gonzalez DG, Kleinstein SH, et al. Germinal center B cell and T follicular helper cell development initiates in the interfollicular zone. Immunity. 2011; 34(6):947-60. [PubMed: 21636295]

16. Qi H, Cannons JL, Klauschen F, Schwartzberg PL, Germain RN. SAP-controlled T-B cell interactions underlie germinal centre formation. Nature. 2008; 455(7214):764-9. [PubMed: 18843362]

17. Zaretsky AG, Taylor JJ, King IL, Marshall FA, Mohrs M, Pearce EJ. T follicular helper cells differentiate from Th2 cells in response to helminth antigens. J Exp Med. 2009; 206(5):991-9. [PubMed: 19380637]

18. Germain RN, Robey EA, Cahalan MD. A decade of imaging cellular motility and interaction dynamics in the immune system. Science. 2012; 336(6089):1676-81. [PubMed: 22745423]

19. Baumjohann D, Preite S, Reboldi A, Ronchi F, Ansel KM, Lanzavecchia A, et al. Persistent antigen and germinal center B cells sustain $\mathrm{T}$ follicular helper cell responses and phenotype. Immunity. 2013; 38(3):596-605. [PubMed: 23499493]

20. Good-Jacobson KL, Szumilas CG, Chen L, Sharpe AH, Tomayko MM, Shlomchik MJ. PD-1 regulates germinal center B cell survival and the formation and affinity of long-lived plasma cells. Nature immunology. 2010; 11(6):535-42. [PubMed: 20453843]

21. Choi YS, Yang JA, Yusuf I, Johnston RJ, Greenbaum J, Peters B, et al. Bcl6 expressing follicular helper CD4 T cells are fate committed early and have the capacity to form memory. J Immunol. 2013; 190(8):4014-26. [PubMed: 23487426]

22. Crawford A, Macleod M, Schumacher T, Corlett L, Gray D, Primary T. cell expansion and differentiation in vivo requires antigen presentation by B cells. J Immunol. 2006; 176(6):3498506. [PubMed: 16517718]

23. Forster R, Davalos-Misslitz AC, Rot A. CCR7 and its ligands: balancing immunity and tolerance. Nature reviews. Immunology. 2008; 8(5):362-71. [PubMed: 18379575]

24. Weaver CT, Hatton RD, Mangan PR, Harrington LE. IL-17 family cytokines and the expanding diversity of effector T cell lineages. Annual review of immunology. 2007; 25:821-52.

25. Pulendran B, Tang H, Manicassamy S. Programming dendritic cells to induce $\mathrm{T}(\mathrm{H}) 2$ and tolerogenic responses. Nature immunology. 2010; 11(8):647-55. [PubMed: 20644570] 
26. Matloubian M, Cyster JG. Th1 cell induction in lymph nodes according to a red-blue chemokine map. Immunity. 2012; 37(6):954-6. [PubMed: 23244716]

27. Groom JR, Richmond J, Murooka TT, Sorensen EW, Sung JH, Bankert K, et al. CXCR3 chemokine receptor-ligand interactions in the lymph node optimize CD4+ T helper 1 cell differentiation. Immunity. 2012; 37(6):1091-103. [PubMed: 23123063]

28. Leon B, Ballesteros-Tato A, Browning JL, Dunn R, Randall TD, Lund FE. Regulation of T(H)2 development by CXCR5+ dendritic cells and lymphotoxin-expressing B cells. Nature immunology. 2012; 13(7):681-90. [PubMed: 22634865]

29. Randolph DA, Huang G, Carruthers CJ, Bromley LE, Chaplin DD. The role of CCR7 in TH1 and TH2 cell localization and delivery of B cell help in vivo. Science. 1999; 286(5447):2159-62. [PubMed: 10591648]

30. Hardtke S, Ohl L, Forster R. Balanced expression of CXCR5 and CCR7 on follicular T helper cells determines their transient positioning to lymph node follicles and is essential for efficient B-cell help. Blood. 2005; 106(6):1924-31. [PubMed: 15899919]

31. Ansel KM, Ngo VN, Hyman PL, Luther SA, Forster R, Sedgwick JD, et al. A chemokine-driven positive feedback loop organizes lymphoid follicles. Nature. 2000; 406(6793):309-14. [PubMed: 10917533]

32. Liu X, Yan X, Zhong B, Nurieva RI, Wang A, Wang X, et al. Bcl6 expression specifies the T follicular helper cell program in vivo. The Journal of experimental medicine. 2012; 209(10):184152. S1-24. [PubMed: 22987803]

33. Fillatreau S, Gray D. T cell accumulation in B cell follicles is regulated by dendritic cells and is independent of B cell activation. The Journal of experimental medicine. 2003; 197(2):195-206. [PubMed: 12538659]

34. Saeki H, Wu MT, Olasz E, Hwang ST. A migratory population of skin-derived dendritic cells expresses CXCR5, responds to B lymphocyte chemoattractant in vitro, and co-localizes to B cell zones in lymph nodes in vivo. European journal of immunology. 2000; 30(10):2808-14. [PubMed: 11069061]

35. Yu P, Wang Y, Chin RK, Martinez-Pomares L, Gordon S, Kosco-Vibois MH, et al. B cells control the migration of a subset of dendritic cells into B cell follicles via CXC chemokine ligand 13 in a lymphotoxin-dependent fashion. J Immunol. 2002; 168(10):5117-23. [PubMed: 11994465]

36. Berney C, Herren S, Power CA, Gordon S, Martinez-Pomares L, Kosco-Vilbois MH. A member of the dendritic cell family that enters B cell follicles and stimulates primary antibody responses identified by a mannose receptor fusion protein. The Journal of experimental medicine. 1999; 190(6):851-60. [PubMed: 10499923]

37. Lambrecht BN, Hammad H. Lung dendritic cells in respiratory viral infection and asthma: from protection to immunopathology. Annual review of immunology. 2012; 30:243-70.

38. Leon B, Lopez-Bravo M, Ardavin C. Monocyte-derived dendritic cells formed at the infection site control the induction of protective T helper 1 responses against Leishmania. Immunity. 2007; 26(4):519-31. [PubMed: 17412618]

39. Nakano H, Lin KL, Yanagita M, Charbonneau C, Cook DN, Kakiuchi T, et al. Blood-derived inflammatory dendritic cells in lymph nodes stimulate acute $\mathrm{T}$ helper type 1 immune responses. Nature immunology. 2009; 10(4):394-402. [PubMed: 19252492]

40. Ballesteros-Tato A, Leon B, Lund FE, Randall TD. Temporal changes in dendritic cell subsets, cross-priming and costimulation via CD70 control CD8(+) T cell responses to influenza. Nature immunology. 11(3):216-24. [PubMed: 20098442]

41. Randolph GJ, Ochando J, Partida-Sanchez S. Migration of dendritic cell subsets and their precursors. Annual review of immunology. 2008; 26:293-316.

42. Plantinga M, Guilliams M, Vanheerswynghels M, Deswarte K, Branco-Madeira F, Toussaint W, et al. Conventional and monocyte-derived $\mathrm{CD} 11 \mathrm{~b}(+)$ dendritic cells initiate and maintain $\mathrm{T}$ helper 2 cell-mediated immunity to house dust mite allergen. Immunity. 2013; 38(2):322-35. [PubMed: 23352232]

43. Kim TS, Braciale TJ. Respiratory dendritic cell subsets differ in their capacity to support the induction of virus-specific cytotoxic CD8+ T cell responses. PloS one. 2009; 4(1):e4204.

[PubMed: 19145246] 
44. Saeki H, Moore AM, Brown MJ, Hwang ST. Cutting edge: secondary lymphoid-tissue chemokine (SLC) and CC chemokine receptor 7 (CCR7) participate in the emigration pathway of mature dendritic cells from the skin to regional lymph nodes. J Immunol. 1999; 162(5):2472-5. [PubMed: 10072485]

45. Braun A, Worbs T, Moschovakis GL, Halle S, Hoffmann K, Bolter J, et al. Afferent lymph-derived $\mathrm{T}$ cells and DCs use different chemokine receptor CCR7-dependent routes for entry into the lymph node and intranodal migration. Nature immunology. 2011; 12(9):879-87. [PubMed: 21841786]

46. Forster R, Schubel A, Breitfeld D, Kremmer E, Renner-Muller I, Wolf E, et al. CCR7 coordinates the primary immune response by establishing functional microenvironments in secondary lymphoid organs. Cell. 1999; 99(1):23-33. [PubMed: 10520991]

47. Ohl L, Mohaupt M, Czeloth N, Hintzen G, Kiafard Z, Zwirner J, et al. CCR7 governs skin dendritic cell migration under inflammatory and steady-state conditions. Immunity. 2004; 21(2): 279-88. [PubMed: 15308107]

48. Belz GT, Smith CM, Kleinert L, Reading P, Brooks A, Shortman K, et al. Distinct migrating and nonmigrating dendritic cell populations are involved in MHC class I-restricted antigen presentation after lung infection with virus. Proceedings of the National Academy of Sciences of the United States of America. 2004; 101(23):8670-5. [PubMed: 15163797]

49. den Haan JM, Lehar SM, Bevan MJ. CD8(+) but not CD8(-) dendritic cells cross-prime cytotoxic T cells in vivo. The Journal of experimental medicine. 2000; 192(12):1685-96. [PubMed: 11120766]

50. Allan RS, Waithman J, Bedoui S, Jones CM, Villadangos JA, Zhan Y, et al. Migratory dendritic cells transfer antigen to a lymph node-resident dendritic cell population for efficient CTL priming. Immunity. 2006; 25(1):153-62. [PubMed: 16860764]

51. Carbone FR, Belz GT, Heath WR. Transfer of antigen between migrating and lymph node-resident DCs in peripheral T-cell tolerance and immunity. Trends in immunology. 2004; 25(12):655-8. [PubMed: 15530835]

52. Yoo JK, Fish EN, Braciale TJ. LAPCs promote follicular helper T cell differentiation of Agprimed CD4+ T cells during respiratory virus infection. The Journal of experimental medicine. 2012; 209(10):1853-67. [PubMed: 22987801]

53. Bachmann MF, Kopf M, Marsland BJ. Chemokines: more than just road signs. Nature reviews. Immunology. 2006; 6(2):159-64.

54. Marsland BJ, Battig P, Bauer M, Ruedl C, Lassing U, Beerli RR, et al. CCL19 and CCL21 induce a potent proinflammatory differentiation program in licensed dendritic cells. Immunity. 2005; 22(4):493-505. [PubMed: 15845453]

55. Yanagawa Y, Onoe K. CCR7 ligands induce rapid endocytosis in mature dendritic cells with concomitant up-regulation of Cdc42 and Rac activities. Blood. 2003; 101(12):4923-9. [PubMed: 12609829]

56. Choi YS, Yang JA, Crotty S. Dynamic regulation of Bc16 in follicular helper CD4 T (Tfh) cells. Current opinion in immunology. 2013; 25(3):366-72. [PubMed: 23688737]

57. Cannons JL, Lu KT, Schwartzberg PL. T follicular helper cell diversity and plasticity. Trends in immunology. 2013; 34(5):200-7. [PubMed: 23395212]

58. Choi YS, Eto D, Yang JA, Lao C, Crotty S. Cutting edge: STAT1 is required for IL-6-mediated Bc16 induction for early follicular helper cell differentiation. J Immunol. 2013; 190(7):3049-53. [PubMed: 23447690]

59. Eto D, Lao C, DiToro D, Barnett B, Escobar TC, Kageyama R, et al. IL-21 and IL-6 are critical for different aspects of B cell immunity and redundantly induce optimal follicular helper CD4 T cell (Tfh) differentiation. PloS one. 2011; 6(3):e17739. [PubMed: 21423809]

60. Nurieva RI, Chung Y, Hwang D, Yang XO, Kang HS, Ma L, et al. Generation of T follicular helper cells is mediated by interleukin-21 but independent of T helper 1, 2, or 17 cell lineages. Immunity. 2008; 29(1):138-49. [PubMed: 18599325]

61. Vogelzang A, McGuire HM, Yu D, Sprent J, Mackay CR, King C. A fundamental role for interleukin-21 in the generation of T follicular helper cells. Immunity. 2008; 29(1):127-37. [PubMed: 18602282] 
62. Nurieva RI, Podd A, Chen Y, Alekseev AM, Yu M, Qi X, et al. STAT5 protein negatively regulates $\mathrm{T}$ follicular helper ( $\mathrm{Tfh}$ ) cell generation and function. The Journal of biological chemistry. 2012; 287(14):11234-9. [PubMed: 22318729]

63. Johnston RJ, Choi YS, Diamond JA, Yang JA, Crotty S. STAT5 is a potent negative regulator of TFH cell differentiation. The Journal of experimental medicine. 2012; 209(2):243-50. [PubMed: 22271576]

64. Harker JA, Lewis GM, Mack L, Zuniga EI. Late interleukin-6 escalates T follicular helper cell responses and controls a chronic viral infection. Science. 2011; 334(6057):825-9. [PubMed: 21960530]

65. Ferrer IR, Liu D, Pinelli DF, Koehn BH, Stempora LL, Ford ML. CD40/CD154 blockade inhibits dendritic cell expression of inflammatory cytokines but not costimulatory molecules. J Immunol. 2012; 189(9):4387-95. [PubMed: 23002440]

66. Cucak H, Yrlid U, Reizis B, Kalinke U, Johansson-Lindbom B. Type I interferon signaling in dendritic cells stimulates the development of lymph-node-resident $\mathrm{T}$ follicular helper cells. Immunity. 2009; 31(3):491-501. [PubMed: 19733096]

67. Naranjo-Gomez M, Oliva H, Climent N, Fernandez MA, Ruiz-Riol M, Bofill M, et al. Expression and function of the IL-2 receptor in activated human plasmacytoid dendritic cells. European journal of immunology. 2007; 37(7):1764-72. [PubMed: 17523134]

68. Bonnefoy F, Couturier M, Clauzon A, Remy-Martin JP, Gaugler B, Tiberghien P, et al. TGF-betaexposed plasmacytoid dendritic cells participate in Th17 commitment. J Immunol. 2011; 186(11): 6157-64. [PubMed: 21518970]

69. Jego G, Palucka AK, Blanck JP, Chalouni C, Pascual V, Banchereau J. Plasmacytoid dendritic cells induce plasma cell differentiation through type I interferon and interleukin 6. Immunity. 2003; 19(2):225-34. [PubMed: 12932356]

70. Ogata M, Ito T, Shimamoto K, Nakanishi T, Satsutani N, Miyamoto R, et al. Plasmacytoid dendritic cells have a cytokine-producing capacity to enhance ICOS ligand-mediated IL-10 production during T-cell priming. International immunology. 2013; 25(3):171-82. [PubMed: 23125331]

71. Ito T, Yang M, Wang YH, Lande R, Gregorio J, Perng OA, et al. Plasmacytoid dendritic cells prime IL-10-producing T regulatory cells by inducible costimulator ligand. The Journal of experimental medicine. 2007; 204(1):105-15. [PubMed: 17200410]

72. Conrad C, Gregorio J, Wang YH, Ito T, Meller S, Hanabuchi S, et al. Plasmacytoid dendritic cells promote immunosuppression in ovarian cancer via ICOS costimulation of Foxp3(+) T-regulatory cells. Cancer research. 2012; 72(20):5240-9. [PubMed: 22850422]

73. Faget J, Bendriss-Vermare N, Gobert M, Durand I, Olive D, Biota C, et al. ICOS-ligand expression on plasmacytoid dendritic cells supports breast cancer progression by promoting the accumulation of immunosuppressive CD4+ T cells. Cancer research. 2012; 72(23):6130-41. [PubMed: 23026134]

74. GeurtsvanKessel CH, Willart MA, van Rijt LS, Muskens F, Kool M, Baas C, et al. Clearance of influenza virus from the lung depends on migratory langerin+CD11b- but not plasmacytoid dendritic cells. The Journal of experimental medicine. 2008; 205(7):1621-34. [PubMed: 18591406]

75. Kim SJ, Zou YR, Goldstein J, Reizis B, Diamond B. Tolerogenic function of Blimp-1 in dendritic cells. The Journal of experimental medicine. 2011; 208(11):2193-9. [PubMed: 21948081]

76. Chan YH, Chiang MF, Tsai YC, Su ST, Chen MH, Hou MS, et al. Absence of the transcriptional repressor Blimp-1 in hematopoietic lineages reveals its role in dendritic cell homeostatic development and function. J Immunol. 2009; 183(11):7039-46. [PubMed: 19915049]

77. Oestreich KJ, Mohn SE, Weinmann AS. Molecular mechanisms that control the expression and activity of Bcl-6 in TH1 cells to regulate flexibility with a TFH-like gene profile. Nature immunology. 2012; 13(4):405-11. [PubMed: 22406686]

78. Granucci F, Vizzardelli C, Pavelka N, Feau S, Persico M, Virzi E, et al. Inducible IL-2 production by dendritic cells revealed by global gene expression analysis. Nature immunology. 2001; 2(9): 882-8. [PubMed: 11526406] 
79. Granucci F, Feau S, Angeli V, Trottein F, Ricciardi-Castagnoli P. Early IL-2 production by mouse dendritic cells is the result of microbial-induced priming. J Immunol. 2003; 170(10):5075-81. [PubMed: 12734352]

80. Andrews DM, Andoniou CE, Granucci F, Ricciardi-Castagnoli P, Degli-Esposti MA. Infection of dendritic cells by murine cytomegalovirus induces functional paralysis. Nature immunology. 2001; 2(11):1077-84. [PubMed: 11668340]

81. Liao W, Schones DE, Oh J, Cui Y, Cui K, Roh TY, et al. Priming for T helper type 2 differentiation by interleukin 2-mediated induction of interleukin 4 receptor alpha-chain expression. Nature immunology. 2008; 9(11):1288-96. [PubMed: 18820682]

82. Liao W, Lin JX, Wang L, Li P, Leonard WJ. Modulation of cytokine receptors by IL-2 broadly regulates differentiation into helper T cell lineages. Nature immunology. 2011; 12(6):551-9. [PubMed: 21516110]

83. Wuest SC, Edwan JH, Martin JF, Han S, Perry JS, Cartagena CM, et al. A role for interleukin-2 trans-presentation in dendritic cell-mediated $\mathrm{T}$ cell activation in humans, as revealed by daclizumab therapy. Nature medicine. 2011; 17(5):604-9.

84. Velten FW, Rambow F, Metharom P, Goerdt S. Enhanced T-cell-activation and T-cell-dependent IL-2 production by CD83+, CD25high, CD43high human monocyte-derived dendritic cells. Molecular immunology. 2007; 44(7):1544-50. [PubMed: 17023048]

85. Fukao T, Koyasu S. Expression of functional IL-2 receptors on mature splenic dendritic cells. European journal of immunology. 2000; 30(5):1453-7. [PubMed: 10820393]

86. Nakayamada S, Kanno Y, Takahashi H, Jankovic D, Lu KT, Johnson TA, et al. Early Th1 cell differentiation is marked by a Tfh cell-like transition. Immunity. 2011; 35(6):919-31. [PubMed: 22195747]

87. Ma CS, Suryani S, Avery DT, Chan A, Nanan R, Santner-Nanan B, et al. Early commitment of naive human $\mathrm{CD} 4(+) \mathrm{T}$ cells to the $\mathrm{T}$ follicular helper $(\mathrm{T}(\mathrm{FH})$ ) cell lineage is induced by IL-12. Immunology and cell biology. 2009; 87(8):590-600. [PubMed: 19721453]

88. Schmitt N, Morita R, Bourdery L, Bentebibel SE, Zurawski SM, Banchereau J, et al. Human dendritic cells induce the differentiation of interleukin-21-producing $\mathrm{T}$ follicular helper-like cells through interleukin-12. Immunity. 2009; 31(1):158-69. [PubMed: 19592276]

89. Yang Y, Ochando JC, Bromberg JS, Ding Y. Identification of a distant T-bet enhancer responsive to IL-12/Stat4 and IFNgamma/Stat1 signals. Blood. 2007; 110(7):2494500.

90. Schulz EG, Mariani L, Radbruch A, Hofer T. Sequential polarization and imprinting of type $1 \mathrm{~T}$ helper lymphocytes by interferon-gamma and interleukin-12. Immunity. 2009; 30(5):673-83. [PubMed: 19409816]

91. Huang LY, Reis e Sousa C, Itoh Y, Inman J, Scott DE. IL-12 induction by a TH1-inducing adjuvant in vivo: dendritic cell subsets and regulation by IL-10. J Immunol. 2001; 167(3):142330. [PubMed: 11466361]

92. De Smedt T, Butz E, Smith J, Maldonado-Lopez R, Pajak B, Moser M, et al. CD8alpha(-) and CD8alpha(+) subclasses of dendritic cells undergo phenotypic and functional maturation in vitro and in vivo. Journal of leukocyte biology. 2001; 69(6):951-8. [PubMed: 11404381]

93. Hochrein H, Shortman K, Vremec D, Scott B, Hertzog P, O'Keeffe M. Differential production of IL-12, IFN-alpha, and IFN-gamma by mouse dendritic cell subsets. J Immunol. 2001; 166(9): 5448-55. [PubMed: 11313382] 


\section{"Pro-Tfh DC"}

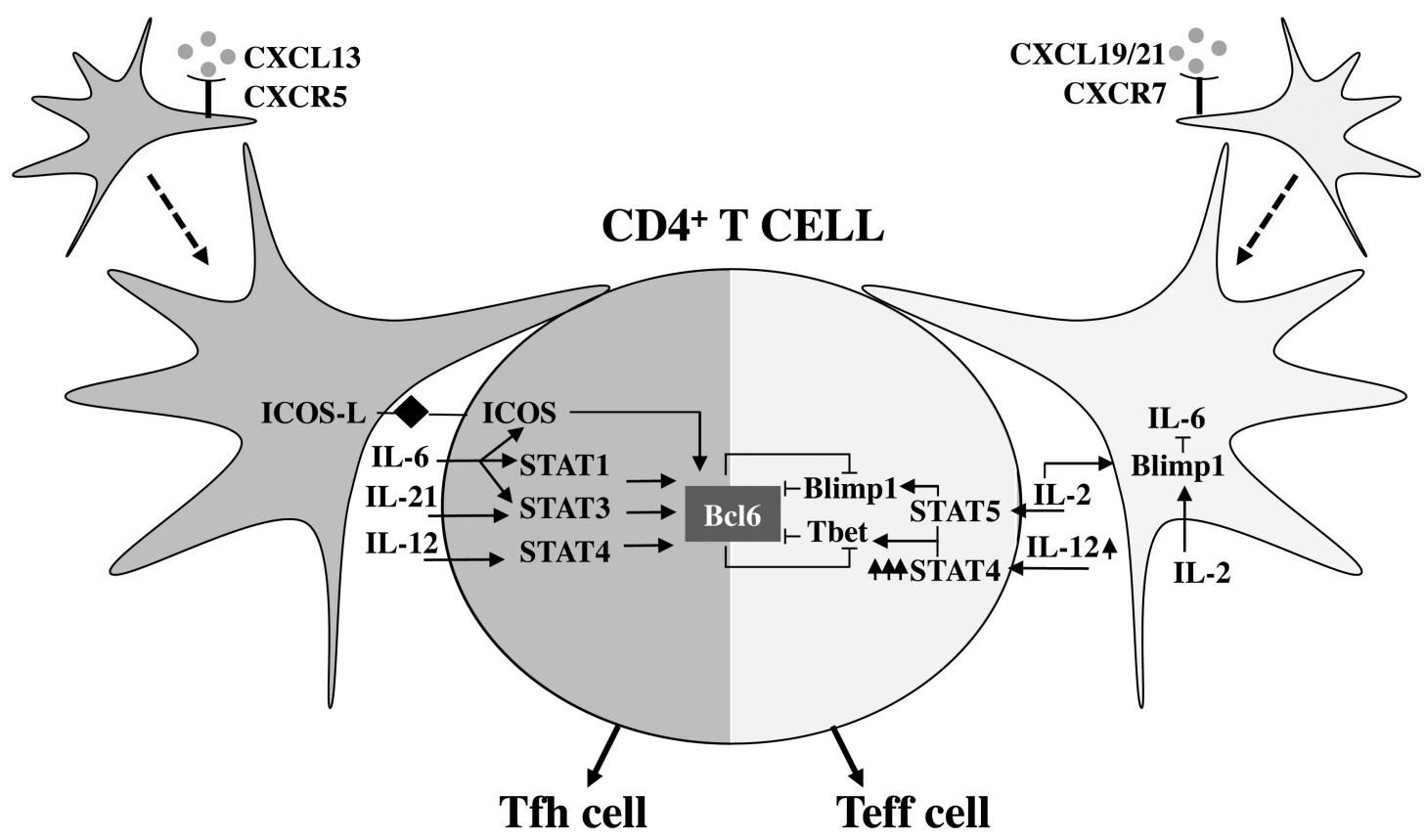

FIGURE 1. Priming of effector and Tfh cell responses by conditioned DCs.

Tfh cell development is regulated by the cross-talk between cytokines that promote Bcl6 expression and the cytokines that prevent it. DCs conditioned to secrete "pro-Tfh cells" cytokines preferentially induce Tfh cell expansion, whereas DCs secreting large amounts of "anti-Tfh cell" cytokines promote effector T cell differentiation. 


\begin{tabular}{|c|c|c|}
\hline DC subset & Origin & Phenotype \\
\hline $\mathrm{CD} 8 \mathrm{a}^{+} \mathrm{rDCs}$ & LN Resident & $\mathrm{MHCII}^{\mathrm{int}} \mathrm{CD} 11 \mathrm{c}^{\mathrm{hi}} \mathrm{B} 220^{-} \mathrm{CD} 103^{\mathrm{hi}} \mathrm{CD} 8 \mathrm{a}^{+} \mathrm{CD} 11 \mathrm{~b}^{-} \mathrm{Ly} 6 \mathrm{C}^{-} \mathrm{CD} 64^{-}{ }^{-} \mathrm{Mar}^{-} \mathrm{CCR} 7^{-}$ \\
\hline $\mathrm{CD} 4^{+} \mathrm{rDCs}$ & LN Resident & $\mathrm{MHCII}^{\mathrm{int}} \mathrm{CD} 11 \mathrm{c}^{\mathrm{hi}} \mathrm{B} 220^{-} \mathrm{CD} 4^{+} \mathrm{CD} 8 \mathrm{a}^{-} \mathrm{CD} 11 \mathrm{~b}^{\mathrm{hi}} \mathrm{Ly} 6 \mathrm{C}^{-} \mathrm{CD} 64^{-} \mathrm{Mar}^{-} \mathrm{CCR} 7^{-}$ \\
\hline $\mathrm{CD} 4 / 8 \mathrm{a}^{-} \mathrm{rDCs}$ & LN Resident & $\mathrm{MHCII}^{\text {int }} \mathrm{CD} 11 \mathrm{c}^{\mathrm{hi}} \mathrm{B} 220^{-} \mathrm{CD} 4^{-} \mathrm{CD} 8 \mathrm{a}^{-} \mathrm{CD} 11 \mathrm{~b}^{\mathrm{hi}} \mathrm{Ly} 6 \mathrm{C}^{-} \mathrm{CD} 64^{-} \mathrm{Mar}^{-} \mathrm{CCR} 7^{-}$ \\
\hline $\mathrm{CD} 103^{+} \mathrm{mDCs}$ & Lung-Migratory & $\mathrm{MHCII}^{\mathrm{hi}} \mathrm{CD} 11 \mathrm{c}^{\mathrm{int}} \mathrm{B} 220^{-} \mathrm{CD} 103^{\text {hi }}$ Lang $^{+} \mathrm{CD} 11 \mathrm{~b}^{\mathrm{lo}} \mathrm{Ly} 6 \mathrm{C}^{\mathrm{lo}} \mathrm{CD} 64^{\mathrm{lo}} \mathrm{Mar} 1^{\mathrm{lo}} \mathrm{CCR} 7^{\mathrm{hi}}$ \\
\hline${ }_{\text {con }} \mathrm{CD} 11 \mathrm{~b}^{+} \mathrm{mDCs}$ & Lung-Migratory & $\mathrm{MHCII}^{\mathrm{hi}} \mathrm{CD} 11^{\mathrm{int}} \mathrm{B} 220^{-} \mathrm{CD} 103^{\text {int }}$ Lang $^{-} \mathrm{CD} 11 \mathrm{~b}^{\mathrm{hi}} \mathrm{Ly} 6 \mathrm{C}^{\mathrm{hi}} \mathrm{CD} 64^{\mathrm{lo}} \mathrm{Mar} 1^{\mathrm{intt}} \mathrm{CCR} 7^{\text {in }}$ \\
\hline${ }_{\mathrm{mo}} \mathrm{CD} 11 \mathrm{~b}^{+} \mathrm{mDCs}$ & Lung-Migratory & MHCII ${ }^{\text {hi }} \mathrm{CD} 11 \mathrm{c}^{\mathrm{int}} \mathrm{B} 220^{-} \mathrm{CD} 103^{\mathrm{lo}}$ Lang $^{-} \mathrm{CD} 11 \mathrm{~b}^{\mathrm{hi}} \mathrm{Ly} 6 \mathrm{C}^{\mathrm{hi}} \mathrm{CD} 64^{\mathrm{hi}}$ Mar $1^{\text {hi }} \mathrm{CCR} 7^{\text {lo }}$ \\
\hline Plasmacytoid DCs & Bone marrow & $\mathrm{MHCII}^{\mathrm{lo}} \mathrm{CD} 11 \mathrm{c}^{\mathrm{int}} \mathrm{B} 220^{+\mathrm{i}} \mathrm{CD} 8 \mathrm{a}^{+/-} \mathrm{CD} 11 \mathrm{~b}^{-} \mathrm{Ly} 6 \mathrm{C}^{+}$ \\
\hline
\end{tabular}

\begin{tabular}{|c|c|c|}
\hline DC subset & Origin & Phenotype \\
\hline $\mathrm{CD} 8 \mathrm{a}^{+} \mathrm{rDCs}$ & LN resident & MHCII ${ }^{\text {int }} \mathrm{CD} 11 \mathrm{c}^{\text {hi }} \mathrm{B} 220^{-} \mathrm{CD} 103^{\mathrm{hi}} \mathrm{CD} 8 \mathrm{a}^{+} \mathrm{CD} 11 \mathrm{~b}^{-} \mathrm{Ly} 6 \mathrm{C}^{-} \mathrm{CD} 64^{-} \mathrm{Mar}^{-} \mathrm{CCR} 7^{-}$ \\
\hline $\mathrm{CD} 4^{+} \mathrm{rDCs}$ & $\mathrm{LN}$ resident & MHCII ${ }^{\text {int }} \mathrm{CD} 11 \mathrm{c}^{\mathrm{hi}} \mathrm{B} 220^{-} \mathrm{CD} 4^{+} \mathrm{CD} 8 \mathrm{a}^{-} \mathrm{CXD} 11 \mathrm{~b}^{\mathrm{hi}} \mathrm{Ly} 6 \mathrm{C}^{-} \mathrm{CD} 64^{-} \mathrm{Mar}^{-} \mathrm{CCR} 7^{-}$ \\
\hline $\mathrm{CD} 4 / 8 \mathrm{a}^{-} \mathrm{rDCs}$ & $\mathrm{LN}$ resident & $\mathrm{MHCII}^{\mathrm{int}} \mathrm{CD} 11 \mathrm{c}^{\text {hi }} \mathrm{B} 220^{-} \mathrm{CD} 4^{-} \mathrm{CD} 8 \mathrm{a}^{-} \mathrm{CD} 11 \mathrm{~b}^{\mathrm{hi}} \mathrm{Ly} 6 \mathrm{C}^{-} \mathrm{CD} 64^{-} \mathrm{Mar}^{-} \mathrm{CCR} 7^{-}$ \\
\hline $\mathrm{CD} 103^{+} \mathrm{mDCs}$ & Lung migratory & MHCII ${ }^{\text {hi }} \mathrm{CD} 11 \mathrm{c}^{\text {int }} \mathrm{B} 220^{-} \mathrm{CD} 103^{\text {hi }}$ Lang $^{+} \mathrm{CD} 11 \mathrm{~b}^{\mathrm{lo}} \mathrm{Ly} 6 \mathrm{C}^{\mathrm{lo}} \mathrm{CD} 64^{\mathrm{lo}} \mathrm{Mar} 1^{\mathrm{lo}} \mathrm{CCR} 7^{\mathrm{hi}}$ \\
\hline${ }_{\mathrm{con}} \mathrm{CD} 11 \mathrm{~b}^{+} \mathrm{mDCs}$ & Lung migratory & $\mathrm{MHCII}^{\mathrm{hi}} \mathrm{CD} 11 \mathrm{c}^{\mathrm{int}} \mathrm{B} 220^{-} \mathrm{CD} 103^{\text {int }}$ Lang $^{-} \mathrm{CD} 11 \mathrm{~b}^{\mathrm{hi}} \mathrm{Ly} 6 \mathrm{C}^{\mathrm{hi}} \mathrm{CD} 64^{\mathrm{lo}} \mathrm{Mar} 1^{\mathrm{int}} \mathrm{CCR} 7^{\text {int }}$ \\
\hline${ }_{\mathrm{mo}} \mathrm{CD} 11 \mathrm{~b}^{+} \mathrm{mDCs}$ & Lung migratory & MHCII ${ }^{\text {hi }} \mathrm{CD} 11 \mathrm{c}^{\mathrm{int}} \mathrm{B} 220^{-} \mathrm{CD} 103^{\mathrm{lo}}$ Lang $^{-} \mathrm{CD} 11 \mathrm{~b}^{\mathrm{hi}} \mathrm{Ly} \mathrm{CC}^{\mathrm{hi}} \mathrm{CD} 64^{\mathrm{hi}} \mathrm{Mar}^{\mathrm{hi}} \mathrm{CCR} 7^{\mathrm{lo}}$ \\
\hline Plasmacytoid DCs & Bone marrow & $\mathrm{MHCII}^{\mathrm{lo}} \mathrm{CD} 11 \mathrm{c}^{\mathrm{int}} \mathrm{B} 220^{+} \mathrm{CD} 8 \mathrm{a}^{+} \mathrm{CD} 11 \mathrm{~b}^{-} \mathrm{Ly}_{6 \mathrm{C}^{+}}$ \\
\hline
\end{tabular}

